\title{
EXPERIMENTAL MANAGEMENT OF A GROUP OF SMALL MICHIGAN LAKES
}

\author{
R. WILLIAM ESCHMEYER \\ Institute for Fisheries Research, Michigan Department of \\ Conservation and University of Michigan.
}

\begin{abstract}
Eight small pit lakes, located in the Pigeon River State Forest, were considered to be ecologically suited to trout as determined by a physical, chemical, and biological survey of these lakes in 1931 and 1932. Four of the lakes were found to be over-run with yellow perch, the other four originally contained only forage fish. Trout (chiefly brook trout) were stocked in each of the lakes. They grew and survived well in those lakes which did not contain perch but were relatively unsuccessful in the "perch" lakes. One of these lakes was fertilized with phosphate and later yielded both trout and perch of fair size, the other three were poisoned and later restocked with trout and, in one instance, with Montana grayling.

The trout were not essily caught in mid-summer, and, for this reason, the lakes were opened to fishing during the repular trout fishing season starting about May first.

Creel census on some of these lakes for several seasons indicates that the yield varied from 4.3 pounde per acre of trout in one lake to 30 pounds per acre of trout in another lake.

These lakes, once valueless for fishing, are now attracting some of the anglers away from the heavily fished, perhaps over-fished, section of the Pigeon River which flows through the immediate vicinity.
\end{abstract}

\section{INTRODUCTION}

The Pigeon River State Forest, a tract of about 113,000 acres of sandy soil in the north central part of the Lower Peninsula of Michigan, has within its boundaries a group of small lakes locally known as "pot-holes." These lakes correspond with the description and figure of a typical pit lake as given by Scott (1921) who states that "this type of lake was probably formed by the isolation of an ice block which became covered with debris and melted later, allowing the material to settle." The lakes are circular in outline with high, steep, sandy banks.

As a result of a proposed program of land utilization for the forest, these pit lakes, nine in number, were inventoried, along with other lakes in the forest, by the Institute for Fisheries Research in 1931 and 1932 and a program for experimental management of the lakes was set up. One of them was too shallow to be of value for desired species of fish, the other eight are discussed below.

In managing these lakes emphasis has been placed on trout. That portion of the Pigeon River which flows through the immediate vicinity of the lakes is heavily fished. In recent years it has given only mediocre results as a trout stream. It was felt that if 


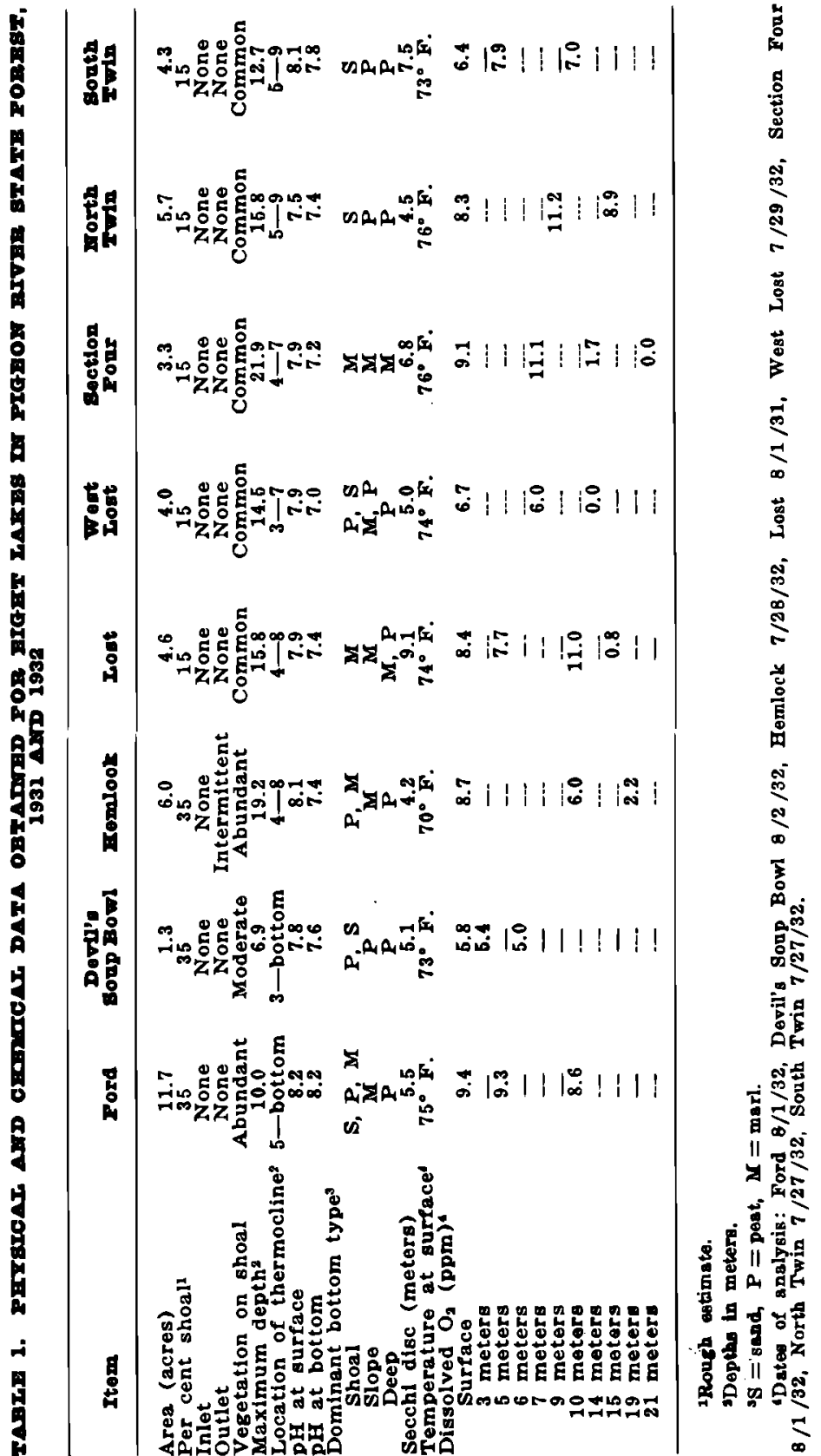


good trout fishing could be provided in these small lakes the angling pressure on the river would probably be diminished.

\section{INVENTORY}

A physical, chemical and biological survey of these eight pit lakes indicates (Table 1) that they vary in size from 1.3 acres to 11.7 acres and in depth from 22 feet in Devil's Soup Bowl to 72 feet in Section Four Lake; all are alkaline and all are stratified, with relatively warm surface water $\left(70^{\circ} \mathrm{F}\right.$. to $76^{\circ} \mathrm{F}$. surface temperature on dates shown in Table 1) but with oxygen ample for fish life in the colder water below the thermocline. The water is clear in all the lakes: Secchi disc readings varied from $131 / 2$ feet in Hemlock Lake to 30 feet in Lost Lake. Five of the lakes (Lost, West Lost, North and South Twin and Section Four) are almost perfectly circular, are land-locked, have very limited shoal areas and relatively scant vegetation. The other three lakes are similar except that Devil's Soup Bowl, the smallest and shallowest, has more vegetation, Hemlock has an intermittent outlet with a weedy, marshy border adjacent, and Ford Lake, the largest, is more irregular, has more shoal area, and somewhat more vegetation.

A study of the fauna (Table 2) showed that all of the lakes contained fish, but that very few species were represented. Yellow perch only were found in three of them; in another a few suckers were taken in addition to perch. The suckers were large and few in number and may have been introduced by anglers $a$ few years before. The other four lakes contained only forage fish until brook trout were stocked in two of them in 1927. Only one species of fish, the fat-headed minnow, was found in the three

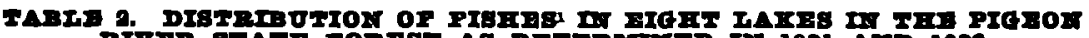
2TV ("A" denoter abundint, "C" common, and "

\begin{tabular}{|c|c|c|c|c|c|c|c|c|c|}
\hline Iake & 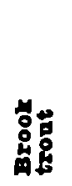 & 造 & 㝵 & 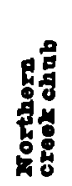 & 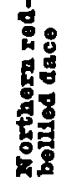 & 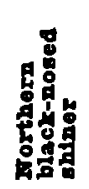 & 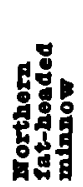 & 害密 & 붕 \\
\hline $\begin{array}{l}\text { Ford } \\
\text { Devil's Soup Bowl } \\
\text { Hemlock } \\
\text { Lost } \\
\text { Wegt Lost } \\
\text { Section Four } \\
\text { North Twin } \\
\text { South Twin }\end{array}$ & $(\text { (A) })^{2}=$ & $\begin{array}{l}\mathbf{A} \\
\mathbf{A} \\
\mathbf{A}\end{array}$ & $\mathbf{R}$ & C & $\mathbf{A}$ & $\mathbf{A}$ & $\begin{array}{l}\mathbf{C} \\
\mathbf{C} \\
\mathbf{A} \\
\mathbf{A}\end{array}$ & C & C \\
\hline
\end{tabular}

\footnotetext{
'Scientific names, corresponding to the common names, in the order listed, are: Salvelinus f. fontinalis Perca flavescens, Oatostomiss c commersonnii, Somotius a. airomaculatus Chrosomus eos, Notropis h. heterolepis, Pimephales p. promelas, Poecilichthys ontis, and Etralia inconstans.

9Gtocked in 1927.
} 
land-locked lakes. Six species were taken in the lake with the intermittent outlet.

From the management angle, the lakes constitute two distinct groups: four containing perch and four without perch. The perch were extremely abundant in the four lakes, but were small, in very poor condition, and were obviously stunted in growth. The brook trout which had been stocked in Lost and Hemlock lakes were in good condition, and in Lost Lake were providing excellent fishing in 1931, when their presence was discovered by the anglers. Until the trout were planted none of the eight lakes was of value for fishing.

\section{Management}

All eight lakes seemed ecologically suited for trout and, in 1933, all were stocked with brook trout by the Oden Hatchery (Table 3). It was understood, of course, that little or no natural reproduction could be expected, because spring fed gravel shoals and tributary streams were lacking; and that stocking would need to be continued at more or less regular intervals if fishing was to be maintained. Four of the lakes have been stocked annually during the last several years.

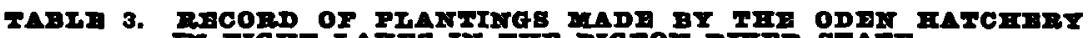

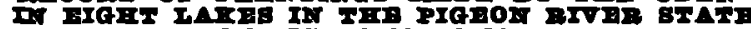

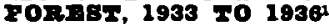

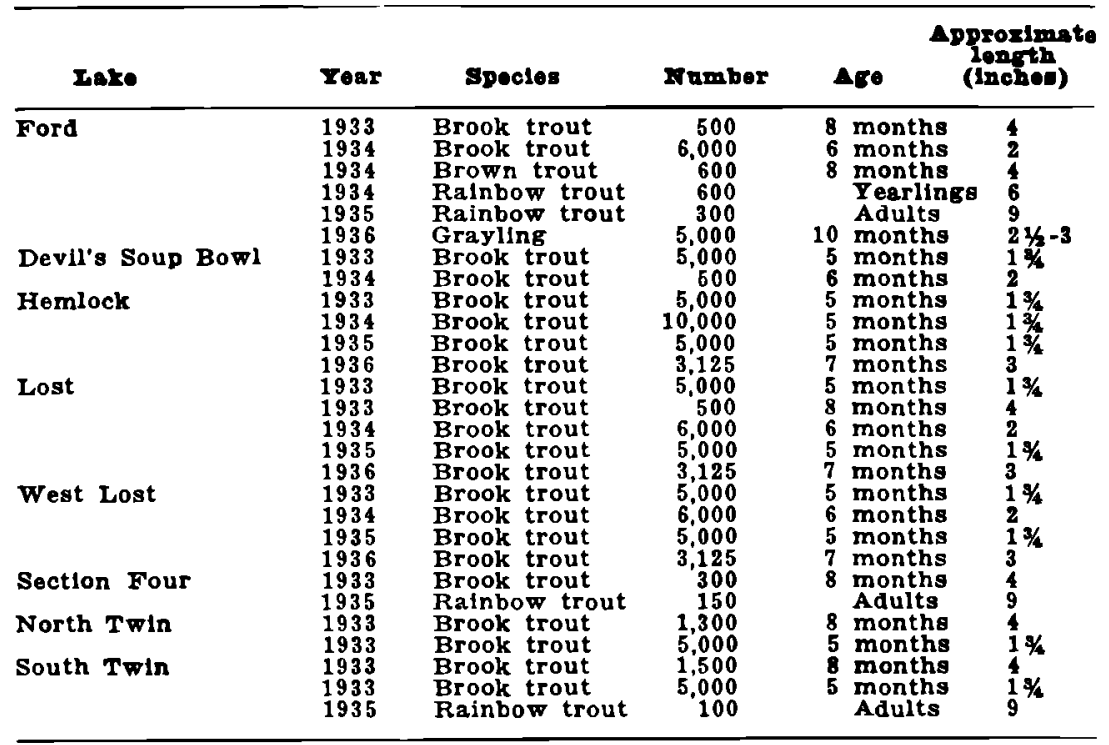

1Mr. Guy Lincoln. District Supervisor of Fisheries, who provided the above dats, indi. cates that the size given is only approximste and thst these sizes refer only to fah from tho Oden Hatehery. The several small plants made by private individuals in 1927 , and the sereral plantings of forage fish made by the writer aro not included in the table: 
The benefits to be derived, in general, from past and current stocking practices for maintenance of our lake fishing are now being questioned to an increasing extent, but in this particular group of lakes stocking is largely responsible for the annual catch of fish.

In recent years the lakes have been designated as "trout" lakes and fishing on them has been permitted during the regular trout fishing season, currently starting on the last Saturday in April. Originally these lakes were closed until June 25 . It seemed desirable to keep the lakes closed to fishing until a relatively late date to accommodate better the heavy mid-summer fishing; but experience has indicated that, in lakes, trout are much more readily taken earlier in the year. An increase in the catch no doubt has resulted from this change in the fishing season. Most of the fish are now taken in May and June.

Management of the four lakes, which did not contain perch, has been limited to stocking with brook trout and to a change in the fishing season. In several of these lakes an excellent yield has resulted. It is reported that recently one of them, Devil's Soup Bowl, has been stocked with brown trout. In the writer's limited experience with brown trout, he has found that this species is not readily caught in lakes. The fishing in Devil's Soup Bowl will be carefully noted to determine the advisability of further introductions of this species.

Stocking of trout in the four lakes containing perch was uniformly unsuccessful. Experimental fishing with gill nets indicated that the growth of the trout in these lakes was very slow and that few of the planted trout survived. The lakes yielded few or no fish of desirable size and were valueless for fishing. Two of them, South Twin and Section Four, were poisoned with rotenone to eradicate the perch and were restocked with adult rainbow trout, the former also with forage fish. A creel census on South Twin Lake indicates that over half of the introduced trout were taken by the anglers during the first season.

North Twin Lake was fertilized. Several hundred pounds of phosphate fertilizer were suspended from a raft in the center of the lake in 1934. Limited returns (general creel census) for the fishing in this lake indicate that in 1936 twenty-one brook trout averaging $111 / 2$ inches in length and forty-eight perch of an average length of $6 \frac{1}{2}$ inches were taken in twenty-two hours of fishing. An intensive creel census now being taken on North Twin Lake indicates that the perch averaged about $71 / 2$ inches in length. It has not been proven that the fertilizer was responsible for the successful growth and survival of the trout or for an apparent increase in the size of the perch; however, in the three lakes which were similar, but which were not fertilized, no such results were obtained. 
$\Delta$ variety of attempts were made to improve fishing in Ford Lake, the largest of the group. All were unsuccessful as long as perch were present. When it was found, in 1934, that the brook trout were not doing well, the lake was heavily netted with gill nets to reduce the population of perch. A total of 1,137 perch (5.6 pounds per acre) was removed. These fish represented one-sixth of the quantity of perch (by weight) which were present in the lake two years later. Several species of forage fish were introduced. The lake was stocked with brook, brown, and rainbow trout in 1935. A few thin and poorly colored trout were caught in 1936 and the lake was still of little value for fishing. The perch had improved in condition but were still growing slowly.

All fish were removed by poisoning with rotenone coupled with heavy dynamiting beginning September 20, 1936. Five thousand Montana grayling fingerlings were stocked on October 31, 1936. An examination of the lake the next spring (May) indicated that the grayling had survived well. The majority of those examined were in good condition and showed reasonable growth. They were not yet of catchable size. Whether or not the lake will eventually provide good grayling fishing still remains to be determined.

\section{Catch}

A knowledge of the catch is necessary if the relative success of the various fish management practices is to be determined adequately. Fortunately it was possible to maintain a complete creel census on Lost, West Lost, and Hemlock lakes in 1935 and on these lakes and South Twin Lake in 1936. The creel census was taken by Camp Pigeon River (M. E. C. W.) and Camp Vanderbilt (U. S. Parks Service). At present a creel census is being taken on all of these lakes except Section Four which is "off the beaten path" and is little fished, and Ford Lake which now contains only small grayling and which is closed to all fishing.

According to the census records (Table 4) the catch in Lost Lake in 1935 consisted of 461 brook trout having an average length of 8.9 inches. The fish had a total weight of 139 pounds. The catch on this 4.6 acre lake was therefore exactly 100 trout or 30.2 pounds per acre. In 1936 the catch was only thirty-six brook

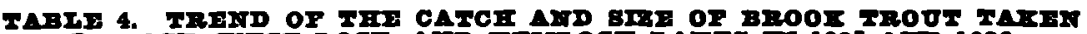

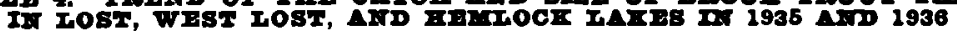

\begin{tabular}{|c|c|c|c|c|}
\hline Taxe & Tear & $\begin{array}{l}\text { Number } \\
\text { canght }\end{array}$ & $\begin{array}{l}\text { Pornde } \\
\text { per acre }\end{array}$ & $\begin{array}{l}\text { Average ntze } \\
\text { (Inchos) }\end{array}$ \\
\hline $\begin{array}{l}\text { Lost } \\
\text { West Lost } \\
\text { Hemlock }\end{array}$ & $\begin{array}{l}1935 \\
1936 \\
1935 \\
1936 \\
1935 \\
1936\end{array}$ & $\begin{array}{r}461 \\
166 \\
199 \\
254 \\
215 \\
52\end{array}$ & $\begin{array}{r}30.2 \\
11.8 \\
23.5 \\
22.5 \\
8.0 \\
4.3\end{array}$ & $\begin{array}{r}8.9 \\
9.3 \\
10.5 \\
9.4 \\
8.1 \\
10.6\end{array}$ \\
\hline
\end{tabular}


trout (12 pounds) per acre. For that year the fish had an average length of 9.3 inches.

Data for the 1931 fishing on Lost Lake, compiled chiefly from the general creel census taken by conservation officers, indicate that by the end of the opening day 162 brook trout averaging 10 inches in length had been caught. Since only 200 trout had been planted (as fingerlings in 1927) fishing was obviously poor for the remainder of the season.

Anglers took fifty fish per acre from West Lost Lake in 1935 and an average of sixty-three and one-half fish per acre the next season. The trout caught in 1935 had an average length of $101 / 2$ inches; in 1936 they averaged an inch shorter. In pounds the catch per acre declined slightly the second year, from $231 / 2$ pounds in 1935 to $221 / 2$ pounds in 1936.

Hemlock Lake yielded good fishing in 1934 according to the writer's frequent observations of this lake during that season. The next year the catch was only 8 pounds per acre and in 1936 only about half that amount. Hemlock Lake is one of the deepest in the group, and temperature and oxygen conditions are favorable for trout. It also appears to be one of the richest in food; the marsh which borders the lake near the outlet seems to be especially productive. The lake has been well stocked with trout. Reasons for the poor yield from Hemlock Lake in recent years have not yet been determined.

The census on South Twin Lake indicates that 62 of the 100 adult rainbows stocked in this lake in the fall of 1935 were caught during the next fishing season.

A study of the effectiveness of the various kinds of bait used failed to show any one bait as outstanding. Minnows and worms were most used. Artificial flies were among the most successful baits.

Anglers were attracted to these small lakes from a wide range of localities. For example, Lost Lake in 1936 was fished by residents from seventeen counties and by non-residents from three states.

\section{Rate of Growth of Brook Trout}

No studies were made of the growth of the trout from scale examinations, but in a few instances some information on growth was obtained as a result of creel census returns. In Lost Lake the fish caught in June, 1931 averaged 10 inches in length. They were four and a fraction years old. Six brook trout taken from Hemlock Lake in 1932 had apparently attained an average length of $191 / 2$ inches in five and a fraction years. One trout taken in Lost Lake in 1935 had a length of 22 inches, and was probably of the original stocking made in 1927 . The 9-inch size group predominated in the 1935 eatch in Lost Lake and the 11-inch size group 
predominated in West Lost Lake. Both were probably two and a fraction years old since these lakes were first stocked in the summer and fall of 1933 (except for the stocking in Lost Lake in 1927) with fish 5 to 8 months old.

\section{Survival of Trout Plantings}

Survival of the stocked fish varied from a fraction of one per cent in one lake to almost a hundred per cent in several small plants. Of the 200 brook trout planted as fingerlings in Lost Lake in 1927, 167 are known to have survived since this number was actually caught. Of the 100 adult rainbow trout planted in South Twin Lake 62 were taken by anglers and 2 were obtained in gill nets set to determine whether the perch had been completely exterminated. Recent examination of the lake, when the trout happened to be feeding at the surface, indicated that most of the remaining thirty-six were still present at the opening of the current fishing season.

After stocking was increased to some hundreds of 5 to 8-monthold trout per acre the number caught represented only a very small percentage of the number planted. Of 16,500 trout planted in Lost Lake from 1933 to 1935 approximately 1,000 were caught in the years 1934 to 1936. Even fewer were taken from West Lost Lake during the same period. This lake had been stocked with a total of $16,000 \mathrm{fish}$ in the three years from 1933 to 1935 .

What happens to the other fish (about 95 per cent of those stocked) is not definitely known. The recent report by one of the census-takers that a large brook trout taken from one of these lakes had six smaller trout in its stomach suggests the possible fate of some of them. A considerable number of the trout probably die at the time of stocking or soon thereafter. Many dead fish were noted by the writer in these lakes in 1934 immediately after they had been planted.

In the lakes over-run with perch, survival of trout was negligible. Of 8,000 trout, including some adults, stocked in Ford Lake, 15 brook trout were taken in gill nets in 1934 and 27 were recovered by the poisoning and dynamiting of the lake in 1936. Very few had been removed by angling.

\section{Survival of Forage Fish}

Two of the lakes, Ford and South Twin, were stocked with forage fish. To improve food conditions in Ford Lake approximately 15,500 fish were planted in July, 1934. These fish, from a beaver pond in a very small tributary of the Pigeon River, were mostly northern dace (Chrosomus eos), although limited numbers of fat-headed minnows (Pimephales promelas), sticklebacks (Eucalia inconstans) and mud minnows (Umbra limi) were included. On the basis of counts along measured sections of the shoreline at the time of the poisoning 
in 1936, the number of forage fish was conservatively estimated to be 36,700 . None was found at the time of the survey in 1932 nor could any have entered by connecting waters since the lake has neither inlet nor outlet. All species which had been planted survived except sticklebacks, and one or more of them had increased in number even though this lake was over-run with perch.

South Twin Lake was stocked with about 5,000 blunt-nosed minnows (Hyborhynchus notatus) and about 50 Menona killifish (Fundulus diaphanus menona). A brief examination of the lake in 1936 indicated that blunt-nosed minnows were abundant. It is possible that the Menona killifish also survived. The lake had been previously poisoned and no fish were present at the time of the stocking with forage fish. Their survival and probable increase in number was therefore not surprising.

\section{PERCH}

The perch which were killed in the three lakes were collected and were later studied in detail. The findings are discussed in two papers by the writer (Eschmeyer, 1937, 1938) and only a few of the details are listed here. Later examinations of the lakes have demonstrated that all perch were probably killed, for gill-net lifts, seine hauls, and creel census records failed to reveal any perch.

In each lake the young fish were dominantly males; the older and larger fish were almost all females. The females grew more rapidly than the males. These findings are in accord with those of HuitfeldtKaas (1927) for the European species, Perca fluviatilis.

The perch grew very slowly in all three of the lakes and few reached a catchable size. In South Twin Lake most of the fish died of starvation before reaching the legal length of 6 inches.

The rate of growth was not correlated with the condition of the fish. Perch which were in excellent condition nevertheless grew quite slowly.

The total population of fish (chiefly perch) per acre varied from 30 pounds in South Twin Lake to 50 pounds in Ford Lake. The number of perch per acre varied from 452 in Ford Lake to 955 in South Twin Lake. The fish of legal length were chiefly females.

An explanation for the more or less frequently observed phenomenon that perch tend to school according to sex was found in Ford Lake. An examination of the stomachs of a hundred perch of each sex taken at the same time by poisoning indicated that the females had been feeding primarily in shallow water. Minnows constituted their chief food and winged ants were prominent in their diet. The males, smaller in size, were apparently in much deeper water. Their food was primarily midge larvae. It seems therefore that the tendency of each sex to school separately may be due to a difference in food habits resulting from a difference in the rate of growth of the two sexes. 


\section{Trend of the Fishina}

On those lakes where a creel census has been taken for several seasons the trend of the yield is definitely downward. It is possible that food may have decreased in two of the lakes. Perhaps they were overstocked. However, food is apparently abundant in Hemlock Lake where fishing for several seasons has been poor. If the fishing in these lakes is to be maintained the reasons for the gradual decline in yield must be determined.

\section{Literature Cited}

Eschmeyer, R. W.

1937. Some characteristies of a population of stunted perch. Papere Mich. Acad. Sci. Arts and Letters, Vol, XXII, pp. 613-628.

1938. Further studies of perch populations. Papers Mich. Acad. Aci. Arts and Letters. Vol. xxiii, pp. 611-631.

Huitfeldt-Kaas, Hartvig.

1927. Studier over aldersforholde og veksttyper hos norske ferskranngfisker. Nationaltrykkeriet. Oslo, Norway. $358 \mathrm{~S}$.

Scott. I. D.

1921. Inland lakes of Michigan. Mich. Geol. and Biol. Survey, Pub. 30, Geol. Series 25, 383 pp. 